\title{
An Investigation of the relationship between EFL hyperactive Young Learners' oral performance and their FL Anxiety
}

\author{
Authors: Nahed Osama Mohamed \\ Dr Mohamed Farouk Abd Al- Samie Ali \\ Dr Sayed Garhi
}

\section{Abstract}

The research paper investigated the relationship between language anxiety and oral performance of hyperactive young learners in an EFL educational context. The participants were composed of 41 fifths year primary stage students at Azza Zidan Official Language School, Fayoum Governorate, Egypt. The Study Sample's oral performance was measured by an oral performance test, their hyperactivity was measured using hyperactivity checklist and their FL speaking anxiety was identified using a Foreign Language anxiety Scale, prepared by the researcher. Findings indicated that most participants generally experienced a level of anxiety in the EFL classroom. There was a positive relationship between anxiety and hyperactivity and a negative relationship between oral performance and anxiety. Also results showed a statistically significant correlation between the scores obtained from the oral performance test, hyperactivity and anxiety scale

Keywords: hyperactivity, oral performance, FL language anxiety scale 


\section{الملخص العزبي}

تدور الدراسة الحالية حول التحقق من وجود علاقة بين مستوي الأداء الثفهي للمتعلمين الصغار ذوي فرط الحركة ومستوي القلق لديهم. تكونت العينة من اء تلميذ في الصف الخامس الابتدائي في مدرسة عزة زيدان الرسمية للغات. تتاولت الدراسة فرضان: الفرض الأول: لا توجد علاقة دالة إحصائية بين درجات عينة الدراسة مفرطي الحركة في تطبيق مقياس القلق وبين درجاتهم في اختبار الأداء الثفهي. الفرض الثاني: لا توجد علاقة دالة إحصائية بين درجات عينة الدراسة في تطبيق مقياس فرط الحركة وبين درجاتهم في مقياس القلق. تم تطبيق اختبار الأداء الثفهي ومقياس قلق اللغة الإنجليزية ومقياس فرط الحركة وتم تحليل النتائج احصائيا. تم رفض فرضي الدراسة حيث ثبتت أنه توجد علاقة بين الأداء الثفهي وفرط الحركة والقلق. توصلت النتائج الي انه أغلب التلاميذ قد خبروا مستوي من قلق اللغة داخل الصف ويزداد هذا القلق مع وجود اضطر اب فرط الحركة مما أثز بالسلب علي أدائهم الثفوي. أيضا أظهرت النتائج ان هناك علاقة إيجابية بين القلق وفرط الحركة فكلما زاد أحدها زاد الأخر • بالإضافة انه توجد علاقة سلبية بين درجات التلاميذ في اختبار الأداء الثفهي وكل من مقياسي القلق بلق وفرط الحركة. اقترحت الدراسة تطبيق مقياس القلق على بعض مهارات اللغة الأخرى

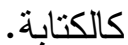




\section{Introduction}

Learning English as a foreign language has always been a problematic area for students whose native language is not English. English is learned as a foreign language (EFL) in Egypt, but we suffer from the limited opportunities to practice or use it in an everyday life environment. Hence in this EFL environment, students are very likely to experience a certain level of language anxiety, which has been found to have some damaging effect on language learning acquisition (Abu-Rabia, 2004, Ay, 2010, Chen \& Chang, 2004; Cheng, 2005).

For many years, researchers and teachers ignored the student's oral ability to communicate in favor of their linguistic ability. One of the challenges faced by EFL participants is expressing themselves clearly and fluently (Hellstén \& Prescott, Liu \& Jackson, 2008, Zhang \& Mi, 2009). Previous research indicated that low oral performance in public schools is caused by three main features. First, teaching practices in public schools focus on vocabulary memorization. Second, activities in English classes tend to be non-communicative. Finally, there are contextual constraints of space, time, and resources (ihmuda,2014)

Any communication problem that people face results in difficulties and limitations at many levels especially in their learning contexts (Gan, 2012). Language difficulties and limitations in either the production or understanding of language are more common in children with a wide variety of psychiatric disorders and this is also the case in children with hyperactivity. Society has become more interested in hyperactivity as one of several disorders affecting a child life at home and in the school environment. However, public awareness about the disorder and its social acceptance are still rather low. The following symptoms have been described as characteristic of hyperactivity: Fidget and squirm in their seats, talk nonstop, dash around, touching or playing with anything and everything in sight, have trouble sitting still during dinner, school, and story time, be

\section{5}


constantly in motion and have difficulty doing quiet tasks or activities (American Psycatric Association, 2013; hereafter abbreviated as APA).

Most of the learners express their fears and a feeling of uneasiness against learning English as a foreign language. The feeling of anxiety can provoke many problems in the acquisition, retention and production of the language which ultimately affects their grades, as compared to their more relaxed peers. Prior research on language anxiety has consistently shown that this unique type of apprehension can exert debilitating effects on language learning and especially on oral performance (Awan et.al., 2010, Ay, 2010, Liu, 2016, Yan,2008) Speaking a foreign language is a source of anxiety for most students. Research shows different sources of language anxiety. Horwitz et al. (1986) refers to three primary language performance anxieties: "social evaluation", "test anxiety", and "communication apprehension". The current study aims to add to the understanding of the relation between hyperactivity and foreign language anxiety and also their effect on oral performance among the young learners.

\section{Statement of the problem}

Foreign language classroom anxiety (FLCA) is still considered to be a relatively new and developing area within foreign language research (Piniel, 2006) and despite the growing number of researches dealing with foreign language anxiety (FLA), there is a limited number of studies involving hyperactive students at the primary stage in Egypt. In addition, due to the negative effects that speaking anxiety have on students' language development in general and their oral performance in particular (Subasi,2010), there is a need to investigate the relationship between students' oral performance and their FL speaking anxiety in order to provide help to reduce students' speaking anxiety level. 
In order to investigate the relationship between EFL hyperactive young learners' oral performance and their FL speaking anxiety, the researcher had to answer the following research main question:

"What is the correlational relationship between fifth year hyperactive primary stage students' oral performance and their FL anxiety?

The following questions are addressed in the present research:

1. What is the level of fifth year official language primary stage students' oral performance?

2. How much FL speaking anxiety do fifth year official language primary stage students undergo during oral performance?

3. What is the correlational relationship between EFL fifth year primary stage students' hyperactivity and their FL anxiety?

4. What is the correlational relationship between EFL fifth year official language primary stage students' oral performance and their FL anxiety?

\section{Aims of the Study}

The current study aimed at identifying the following:

1. The relationship between EFL fifth year official language primary stage students' oral performance and their FL anxiety.

2. The relationship between EFL fifth year official language primary stage students' hyperactivity and their FL anxiety.

\section{Significance of the Study}

\section{The current study might be helpful in:}

1. Providing EFL young learners, teachers, supervisors and researchers with a valid and reliable oral performance test that might help in identifying EFL young learners' oral performance level. 
2. Providing EFL young learners, teachers, supervisors and researchers with a valid and reliable foreign language speaking anxiety scale for measuring EFL young learners' FL anxiety.

3. Raising educators' awareness towards the relationship between EFL young learners' oral performance and their FL anxiety.

4. Raising educators' awareness towards the relationship between EFL young learners' oral performance, hyperactivity and their FL anxiety.

\section{Hypotheses of the study}

\section{The current study aimed at testing the following hypothesis:}

- There is no statistically significant correlation between the study sample's scores in the administration of the FL anxiety scale and the oral performance test

- There is no statistically significant correlation between the study sample's scores in the administration of the hyperactivity checklist and FL Anxiety scale.

\section{Delimitations of the study:}

A sample of forty-one EFL fifth year primary stage students in Azza Zidan Official Language School, Fayoum Governorate. The first semester of the academic year 2019-2020.

\section{Definitions of terms}

The following definitions of key terms are adopted in the current study:

\section{Oral performance}

The ability of the learner to participate in an interaction with one person or more to convey and express his own thoughts, ideas, wishes, opinions, attitudes, information. The learner speaks in understandable words and sentences, at the right voice, and speed, with correct sentence rhythm, with the right tone and with adequate grammatical correctness that holds the listener's attention. Moreover, he produces continuous speech without any breakdowns while 
making appropriate eye-contact with the listener and showing appropriate body-language to support his speech. Also, he avoids distracting movements and gestures.

\section{Hyperactivity}

It is a long life neurodevelopment, biological, and behavioral disorder characterized by hyperactivity and impulsivity that makes learners act without thinking and have trouble following through or sitting still for a period of time or waiting for his turn to answer questions or starting a task or finishing it properly showing poor memorization of data and information, which affects negatively his academic performance and social relations.

\section{FL anxiety}

Abu-Rabia (2004) defined anxiety as "fear, panic, and worry". According to Abu-Rabia (2004), "the foreign language learner characterized as having anxiety is usually worried, physically insecure, and unable to engage in situational learning” (p.712).

The researcher adopted this operational definition in her study:

"The state of worry, insecure and inability of the learner when engaged in an FL situational learning that results in low level of oral performance and increase of hyperactivity"

\section{Literature review}

According to MacIntyre and Gardner (1994), research of the effects of anxiety on language learning has shown an understandable emphasis on the output stage in terms of production, performance, course grades, and other criteria. This is because the performance at output stage is the easiest one to obtain and has been regarded by the majority of teachers and parents as the most important indicator of students' learning. (Richards and Rodgers,2014)

Most researches concerning language anxiety displays the negative effects in most cases. In addition, several studies revealed that language anxiety was negatively correlated with students' 
performances in terms of standardized tests, course grades, and the grades in mid-term exams.

While many researchers have concerned themselves with the effects of anxiety on language acquisition, many others have attempted to identify the factors or sources of this affective variable (Dornyei,2005, Yan \& Horwitz, 2008) such as the psychological perception of the learners towards themselves, becoming anxious when it comes to speaking in front of the others and competitiveness.

Anxiety is usually divided into three different type Trait anxiety, State anxiety, and Situational anxiety. There are three different types of anxiety seen in cases of performance: communication apprehension, test anxiety, and fear of negative evaluation. Speaking demand high levels of concentration in a time frame not controlled by the student. The anxiety experienced in a classroom is called Foreign Language Classroom Anxiety (FLCA).

In studies related to foreign language anxiety, students generally report that speaking in the foreign language classroom produces the highest level of anxiety. FLA is a considerable variable that has negative influences on the foreign language learning process (Aydin, 2008). Prior research affirmed that anxious students: tend to underestimate their ability to speak, focus more on their failures instead of their successes in the foreign language, avoid or withdraw from courses with several communication demands, tend to wait until the end of the lecture to ask a question, not raising their hand, and hoping that somebody else asks the question (Aydin, 2008, Dewaele, et.al., 2015, Tanveer, 2007).

One of the reasons that causes FLA is that achievement is measured and appreciated based solely on test scores rather than whole performance throughout the learning period. Another reason is that comments of others and the teacher during language learning affect language performance. The last reason is that language learners experience communication apprehension during interaction and 
communication with native, second or foreign speakers of the target language. (Liu, 2016, Liu, 2013)

In conclusion, it is important to measure FLA, a considerable issue in the language learning process, with valid and reliable tools to have a deep understanding of how to cope with it.

The FLAS as a widely-acclaimed anxiety scale was developed as a response to the lack of anxiety scales that could measure foreign language anxiety with precision. As a result of the mentioned above, the researcher designed an anxiety scale for younger learners to obtain data on the relationship between hyperactivity and anxiety and their effect on oral performance

The researchers have conducted many studies to examine students' anxiety scores and related it to the oral output. Chan and Wu (2004) examined foreign language anxiety among elementary school children in Taiwan and found that the children not only experienced language anxiety when learning English, but also had final scores that were negatively related to their scores on the anxiety scale. They further identified taking tests, speaking in front of others, speaking to native speakers, spelling, and incomprehensible input as the situations that were most likely to provoke anxiety among the young learners. As anxiety is shown to have a negative impact on language performance, it can also affect many other aspects of language learners, e.g., selfperceived competence self-confidence, and perceived difficulty of a learning task

Baharuddin and Rashid's study (2014) discussed language anxiety and its effect on learning a target language. Participants of the study comprised 70 undergraduate ESL learners of Universiti Putra Malaysia. Findings of the study revealed that the undergraduate ESL learners experienced a medium level of anxiety. English classroom anxiety, communication apprehension, fear of negative evaluation, and test anxiety, were identified as factors that significantly contributed to the language anxiety experienced by the learners. The 
findings suggest that anxiety is a learner variable that needs to be minimized to enhance optimal learning of a target language.

\section{Method}

\section{The study design}

The quasi-experimental design was adopted in the current study. In this study, forty-one students enrolled in the fifth-year primary stage represent the study participants. They belong to one of Fayoum official language schools, namely Azza Zidan Official Language School.

\section{The study variables}

- EFL Fifth year official language primary stage students' oral performance

- EFL Fifth year official language primary stage students' hyperactivity.

- EFL Fifth year official language primary stage students' FL speaking anxiety

\section{The study participants}

The participants of the current study were a group of (41) fifth year primary stage students (one group). The participants were randomly selected from one of Fayoum governmental language schools, namely Azza Zidan language school. Participants' age ranged from 10 to 12 years. The rationale for choosing the sample relied on that in this stage students can be highly recognized as hyperactive or not. In addition, being a hyperactive student at this stage affects their language acquisition in general and especially their oral performance.

\section{The study instruments}

In the current study, the researcher made use of four main instruments:

1. The oral Performance Test

2. The oral Performance Scoring Rubric 
3. The Foreign Language Anxiety Scale.

4. The Hyperactivity checklist

\section{The oral Performance Test}

\subsection{Purpose of the oral Performance Test}

The oral performance test was administered to investigate the level of fifth year hyperactive students' oral performance

\subsection{Design of the oral Performance Test}

The researcher adopted the test based on review of related studies, which discussed the appropriate tasks to be given in order to measure the oral performance rates in young learners. The oral performance test was designed to be a pre-post-test and it consisted of 6 tasks (an ice breaker and 5 tasks). The first was the oral interview task, which aimed at assessing participants' ability to provide information about them and perform social language functions. The second task was the picture identification task and included two pictures, which aimed at extracting ideas of everyday topics and answering questions related to food. The third task was the picture identification task and included 8 pictures, which aimed at identifying different jobs and answering questions related to work life and their dreams for future job. The fourth task was the picture identification task and included, one picture of a daily life of someone which aimed at identifying everyday routine and answering questions related to their daily life. The fifth task was the picture identification task and included 8 pictures, which aimed at identifying different sports and answering questions related to sports. The last task was the picture storytelling task, which aimed at assessing participants' ability to produce oral sentences to describe pictures and narrate a story. (To see the form of the test, please go to appendix A)

\subsection{Validity of the oral Performance Test}

To ensure the validity of the test, the initial version of the test items was submitted to specialized jury members in the field of EFL curricula and instruction to be read and judged as for the following: 
- Suitability of the test items to participants' level.

- Clarity and linguistic correctness of the test items.

- Suitability of the test items for their intended purposes.

The jury members have decided on modifying some questions and the researcher has done the required modifications in the light of the jury member's opinions

\subsection{Reliability of the oral Performance Test}

In order to examine the reliability of the test, it was administered to a randomly assigned sample of fifth year primary school participants (41) at Azza Zidan official language school as a Pilot study one week before implementing the study program. Cronbach's Alpha analysis in the SPSS program was used in order to estimate the reliability of the test. It is clear that all the reliability of the skills and the test as a whole is statistically significant at the lev; of (0.01). Cronbach's Alpha result yielded (0.986) for the whole test, which is a high level of reliability.

\subsection{Time of the oral Performance Test}

To get the average time needed for answering the test, the researcher calculated the time taken by the first student added by the time taken by the last one and divided them by two. The time accredited for answering the test was (16) minutes. Thus, each question within the tasks was given 1/2 minute to be answered, distributed as follows: Oral interview had 6 questions (3 minutes),Picture Description had 5 questions (2 $1 / 2$ minutes), picture description had 6 questions (3 minutes), picture description had 5 questions (2 1/2 minutes),Picture Description had 4 questions (2 minutes), Picture storytelling had 6 pictures and 3 questions ( 3 minutes).

\subsection{Oral Performance Test Scoring}

Students' recordings on the oral performance test were assessed using the oral performance scoring rubric described below. Two raters (the researcher and another rater) used the oral performance scoring rubric to assess learners' oral performance on the test.

\section{4}




\section{The oral Performance Scoring Rubric}

\subsection{Purpose of the oral Performance Scoring Rubric}

An oral performance scoring rubric was prepared by the researcher to rate students' oral performance.

\subsection{Design of the oral Performance Scoring Rubric}

The oral performance rubric was intended to rate participants' oral performance and was designed depending on the review of literature related to assessing participants' oral performance and samples of rubrics designed and applied in several researches and studies. It consisted of 9 criteria to be measured; (Generational Ideas, Pronunciation, Fluency, Accuracy and response delivery, Eye contact, Body language, Facial expression and Gestures). According to the learner's skill, s/he was labelled in one of the 9 criteria which were mentioned in the rubric. For each criterion, 5 levels of rate were introduced (arranged from 1to 5) which meant that the total points of the criterion are 45. (To see the rubric, please go to appendix B)

\subsection{Validity of the oral Performance scoring rubric}

Concerning the validity of the rubric, it was submitted to specialized jury members in the field of EFL curricula and instruction to be read and judged in the light of the following:

- Clarity and relatedness of the rubric rates to their equivalent item.

- Suitability of the rubric items for assessing oral performance.

\subsection{Reliability of the oral Performance Scoring Rubric}

In order to estimate the reliability of the test, a pilot study was conducted where 41 participants were randomly selected from fifth primary stages at Azza Zidan official language school to participate in the oral performance test.

Participants were evaluated and rated using the designed rubric. The researcher made use of the SPSS program to estimate the inter-rater reliability through calculating the correlation between the scores of the skills of the oral performance test and the overall score of the test 
with inter class correlation coefficient statistics. The researcher used the SPSS program in order to estimate the correlation coefficient of the test. the consistency coefficients of oral performance skills with the overall score of oral performance test ranged between 0.637 and 0.925 , all of which are statistically significant correlation coefficients at level 0.01 , which indicates that the test can be viewed with its skills as a unit With the possibility of dealing with the overall degree of any: that the oral performance test is characterized by good internal consistency, and this indicates the validity of oral performance test.

\section{The Foreign Language Anxiety Scale}

\subsection{Purpose of the Foreign Language Anxiety Scale}

The foreign language speaking anxiety scale was designed to identify FL speaking anxiety levels of fifth year official language primary stage students aged 9-12 years old.

\subsection{Design of the Foreign Language Anxiety Scale}

After reviewing several studies on students' FL anxiety, the researcher prepared a FL anxiety scale, taking into account the following points:

- Using items that are positively worded and some items that are negatively worded.

- Using clear, simple and direct items.

-Addressing all FL anxiety dimensions; i.e. cognitive apprehension, communication apprehension, fear of negative evaluation, pressing situation inhibition, and risk-taking reluctance.

The researcher's FL speaking anxiety scale is based on Horwitz et al. (1986) Foreign Language Classroom Anxiety Scale.

The FL anxiety scale consists of (44) items under 7 main pivot that aimed at identifying fifth year official language primary stage students' FL anxiety in terms of Communication Apprehension, Fear of Negative Evaluation, Risk taking Reluctance, pressing Situation inhibitions, Test Anxiety, Fear of making mistakes and Peer approval as components of FL anxiety. Those (44) items were scored on a five- 
point Likert response scale ranging from 1 (strongly disagree) to 5 (strongly agree). A higher score obtained indicated a higher level of FL anxiety and a lower score indicates a lower level of FL anxiety. Ten of the items $(3,7,10,14,21,23,26,27,30$, and 35) are negatively worded and accordingly require reverse scoring before being summed up to yield total scores.

The learner's response is estimated by checking the appropriate box in front of each item, Where:

- 5 means the learner always does this.

- 4 means the learner often does this.

- 3 means the learner sometimes does this.

- 2 means the learner rarely does this.

- 1 means the learner never does this.

The FLAS consisted of 44 items that were assessed on a scale that ranged from one to five (strongly disagree $=1$, disagree $=2$, neither agree nor disagree $=3$, agree $=4$, strongly agree $=5$ ).

\subsection{Validity of the Foreign Language Anxiety Scale}

To ensure the validity of the test, the initial version of the test items was submitted to specialized jury members in the field of EFL curricula and instruction to be read and judged as for the following:

- Check the suitability of the scale for identifying EFL young learners' FL anxiety level.

- Check the clarity and relatedness of the scale dimensions to FL anxiety.

- Check the clarity and relatedness of each indicator to each category

The scale was modified according to the jury members' comments and suggestions (For the final form of the English FL speaking anxiety scale, see appendix D) 


\subsection{Internal Consistency}

Anxiety scale was applied to a survey sample and the internal consistency was tested by calculating the correlation between the score given to each of the dimensions and the total score of the scale.

The correlation between the score given to each of the dimensions of the scale and its total score was calculated, and shown in table (1) below:

\begin{tabular}{|c|c|c|c|}
\hline $\mathbf{N}$ & Items & $\begin{array}{l}\text { Correlation } \\
\text { Coefficient }\end{array}$ & Significance \\
\hline 1 & Communication Apprehension & $\cdot, 9 \wedge r$ & $\cdot, \cdot 1$ \\
\hline 2 & Fear of Negative Evaluation & $\cdot, T r \Lambda$ & $\cdot, \cdot 1$ \\
\hline 3 & Risk taking Reluctance & 0.760 & $\cdot, \cdot 1$ \\
\hline 4 & pressing Situation inhibitions & $\cdot, 90 \mathrm{r}$ & $\cdot, \cdot 1$ \\
\hline 5 & Test Anxiety & 0.760 & $\cdot, \cdot 1$ \\
\hline 6 & Fear of making mistakes & $\cdot, 977$ & $\cdot, \cdot 1$ \\
\hline 7 & Peer approval & $\cdot, 94$. & $\cdot, \cdot 1$ \\
\hline
\end{tabular}

The values given in the above table show the strong correlation between the dimensions of the scale. They were all significantly related to the total score of the scale at (0.01) level and (0.05) level. This means that the FL speaking anxiety scale has an acceptable level of validity.

\subsection{Reliability of the Foreign Language Anxiety Scale}

Cronbach's Alpha analysis in the SPSS program was used in order to examine the reliability of the FL speaking anxiety scale which was applied to a random sample of students. Cronbach's Alpha result yielded (0.866), which is a high level of reliability. 


\section{The Hyperactivity checklist}

\subsection{Purpose of the hyperactivity checklist}

The Hyperactivity checklist was prepared to get baseline data about participants' level in hyperactivity.

\subsection{Design of the hyperactivity checklist}

The researcher constructed the test based on review of related studies, which discussed the appropriate checklists to be given in order to measure the hyperactivity rates in young learners. The researcher builded the checklist in the light of the DSM-5 criterion and modified it to suit the sample. The hyperactivity checklist was designed to be a pre-post checklist and it consisted of 35 items, pivoted under 4 major components of hyperactivity: Physical acts, Attention deficit and Rule breaking acts, Social and emotional acts and Verbal acts. (To see the form of the test, please go to appendix C)

\subsection{Validity of the hyperactivity checklist}

To ensure the validity of the checklist, the initial version of the checklist items was submitted to specialized jury members in the field of mental hygiene and instructed to be read and judged as for the following:

- clarity and accuracy of the directions of the checklist.

-Suitability of the test items for their intended purpose.

-Its form and content.

-Clarity of the items.

-relatedness of the items to the intended purpose.

The jury has decided on modifying some items and the researcher has done the required modifications in the light of the jury member's opinions.

\subsection{Reliability of the hyperactivity checklist}

In order to examine the reliability of the checklist, it was administered to a randomly assigned sample of fifth year primary school 
participants (41) at Azza Zidan official language school as a Pilot study one week before implementing the study program. Cronbach's Alpha analysis in the SPSS program was used in order to estimate the reliability of the checklist. It is clear that all the reliability of the checklist as a whole is statistically significant at the level of (0.01). Cronbach's Alpha result yielded (0.994)

\subsection{Interrater consistency of the hyperactivity checklist}

In order to estimate the reliability of the checklist, a pilot study was conducted where 41 participants were randomly selected from fifth primary stages at Azza Zidan official language school to participate in the hyperactivity checklist.

Participants were evaluated and rated using the designed checklist. The researcher made use of the SPSS program to estimate the interrater reliability through calculating the correlation between the scores of the items of the hyperactivity checklist and the overall score of the hyperactivity checklist with inter class correlation coefficient statistics. The researcher used the SPSS program in order to estimate the correlation coefficient of the test. the coefficients of the consistency of the items of the hyperactivity checklist with the total score of the hyperactivity checklist ranged between 0.996 and 0.998 , all of which are statistically significant correlation coefficients at level 0.01, which indicates that the checklist can be viewed As a whole unit with the possibility of dealing with the overall score of it, Which means that the hyperactivity checklist is characterized by good internal consistency, and this indicates the validity of the hyperactivity checklist.

\section{Procedure}

\section{Tools Implementation}

The study consisted of three main steps: Adaptation, administration and statistical analysis. First, the researcher reviewed the literature related to the scale and adapted the FLAS to be suitable for the special characteristics of suit the young leaners between 9-12 then, 
After establishing the validity, ensuring the reliability and specifying the time of theoral performance test ,hyperactivity checklist and the FL speaking anxiety scale were introduced to a sample of forty one fifth year primary stage students in Azza Zidan official language school, in order to investigate the relationship between oral performance level, hyperactivity and FL anxiety level. The researcher applied the tools in the first semester of the 2019-2020 academic year. Finally, Students' answers were analyzed, and data were collected, recorded, and statistically analyzed to know the correlation between the study sample's oral performance, hyperactivity and their FL writing anxiety. 


\section{Results}

\section{Testing the first hypothesis of the study}

The first hypothesis stated that there was no statistically significant correlation between the study participants' scores in the administration of the FL anxiety scale and the oral performance test. To verify the validity of the hypothesis, the researcher calculated the correlation coefficient between the anxiety level of the fifth-grade hyperactive students and the oral performance level

\section{Table 1}

Statistics of the relationship between the means of scores of FL anxiety of hyperactive fifth year students and their oral performance in the implementation of the oral performance test

\begin{tabular}{|c|c|c|c|c|c|c|c|}
\hline $\begin{array}{c}\text { Oral } \\
\text { performance } \\
\text { components } \\
\text { Anxiety } \\
\end{array}$ & $\begin{array}{c}\text { Task } \\
1\end{array}$ & $\begin{array}{c}\text { Task } \\
2\end{array}$ & $\begin{array}{c}\text { Task } \\
3\end{array}$ & $\begin{array}{c}\text { Task } \\
4\end{array}$ & $\begin{array}{c}\text { Task } \\
5\end{array}$ & $\begin{array}{c}\text { Task } \\
6\end{array}$ & Total \\
\hline $\begin{array}{c}\text { Communication } \\
\text { Apprehension }\end{array}$ & -0.047 & -0.047 & 0.031 & -0.010 & -0.039 & -0.028 & -0.085 \\
\hline $\begin{array}{c}\text { Fear of Negative } \\
\text { Evaluation }\end{array}$ & -0.013 & -0.013 & 0.061 & 0.031 & 0.016 & 0.033 & 0.015 \\
\hline $\begin{array}{l}\text { Risk- taking } \\
\text { Reluctance. }\end{array}$ & -0.075 & -0.075 & -0.041 & -0.042 & -0.039 & -0.069 & -0.037 \\
\hline $\begin{array}{l}\text { pressing Situation } \\
\text { inhibitions }\end{array}$ & -0.061 & -0.061 & 0.022 & -0.010 & -0.041 & -0.035 & -0.064 \\
\hline Test Anxiety & -0.075 & -0.075 & -0.041 & -0.042 & -0.039 & -0.069 & -0.037 \\
\hline $\begin{array}{c}\text { Fear of making } \\
\text { mistakes }\end{array}$ & -0.089 & -0.089 & 0.004 & -0.032 & -0.056 & -0.047 & -0.110 \\
\hline Peer approval. & 0.022 & 0.022 & 0.098 & 0.057 & 0.019 & 0.023 & 0.039 \\
\hline Total & -0.046 & -0.046 & 0.042 & 0.002 & -0.028 & -0.019 & -0.059 \\
\hline
\end{tabular}

The previous table showed that there was a statistically negative correlation between the level of anxiety of the fifth-year students and their oral performance. From the results shown above, the null hypothesis was rejected. 


\section{Testing the Second hypothesis of the study}

The second hypothesis stated that there was no statistically significant correlation between the study sample's scores in the administration of the hyperactivity checklist and their mean scores in FL anxiety scale

\section{Table 2}

Statistics of the relationship between the means of scores of FL anxiety of fifth year students and their hyperactivity in the implementation of the hyperactivity checklist.

\begin{tabular}{|c|c|c|c|c|c|}
\hline $\begin{array}{c}\text { Hyperactivity } \\
\text { Factors } \\
\text { Anxiety }\end{array}$ & $\begin{array}{l}\text { Physical } \\
\text { acts }\end{array}$ & $\begin{array}{c}\text { Attention } \\
\text { deficit } \\
\text { and rule } \\
\text { breaking } \\
\text { acts } \\
\end{array}$ & $\begin{array}{c}\text { Social } \\
\text { and } \\
\text { emotional } \\
\text { acts }\end{array}$ & $\begin{array}{l}\text { Verbal } \\
\text { acts }\end{array}$ & $\begin{array}{c}\text { Total of } \\
\text { Hyperactivity } \\
\text { Factors }\end{array}$ \\
\hline $\begin{array}{c}\text { Communication } \\
\text { Apprehension }\end{array}$ & $0.977 * *$ & $0.971 * *$ & $0.978 * *$ & $0.979 * *$ & $0.978 * *$ \\
\hline $\begin{array}{c}\text { Fear of Negative } \\
\text { Evaluation }\end{array}$ & $0.537 * *$ & $0.528 * *$ & $0.543 * *$ & $0.548 * *$ & $0.538 * *$ \\
\hline $\begin{array}{l}\text { Risk- taking } \\
\text { Reluctance. }\end{array}$ & 0.085 & 0.069 & 0.074 & 0.078 & 0.078 \\
\hline $\begin{array}{l}\text { pressing Situation } \\
\text { inhibitions }\end{array}$ & $0.958 * *$ & $0.957 * *$ & $0.945^{* *}$ & $0.959 * *$ & $0.957 * *$ \\
\hline Test Anxiety & $0.959 * *$ & $0.953 * *$ & $0.956 * *$ & $0.954 * *$ & $0.958 * *$ \\
\hline $\begin{array}{c}\text { Fear of making } \\
\text { mistakes }\end{array}$ & 0.085 & 0.069 & 0.074 & 0.078 & 0.078 \\
\hline Peer approval. & $0.929 * *$ & $0.923 * *$ & $0.927 * *$ & $0.930 * *$ & $0.929 * *$ \\
\hline Total & $0.984 * *$ & $0.978 * *$ & $0.982 * *$ & $0.986^{* *}$ & $0.984 * *$ \\
\hline
\end{tabular}

The sign $(* *)$ indicates that the skill is statistically significant at

\subsection{1 level}

The previous table showed that there was a statistically correlation between the level of anxiety of the fifth year students and their hyperactivity. From the results shown above, the null hypothesis was rejected. Also the relationship was positive except for the third on in anxiety and the items of the hyperactivity and also the fifth one of anxiety and the items of hyperactivity. This indicated that the more hyperactivity was the higher FL anxiety was. 
Also, the researcher calculated the difference between the means of low and high scores of oral performance in relation to hyperactivity and anxiety:

\section{Table 3}

The $T$ value and its statistical significance of difference between the means of low and high scores of oral performance in relation to hyperactivity and anxiety

\begin{tabular}{|c|c|c|c|c|c|c|c|c|c|}
\hline Sig. & $\begin{array}{l}\text { Value } \\
\text { of }(Z)\end{array}$ & $\begin{array}{c}\text { St. } \\
\text { deviation }\end{array}$ & Median & $\begin{array}{l}\text { Sum of } \\
\text { ranks }\end{array}$ & $\begin{array}{c}\text { Mean } \\
\text { of } \\
\text { ranks }\end{array}$ & number & $\begin{array}{c}\text { Interquartile } \\
\text { range }\end{array}$ & Variable & $\mathbf{N}$ \\
\hline \multirow[t]{2}{*}{$\begin{array}{l}\text { Non } \\
\text { sig. }\end{array}$} & \multirow[t]{2}{*}{$\cdot, r T$} & $r q, \ldots$ & $.9, \varepsilon$. & $1 \cdot r, \ldots$ & $1 \cdot, r$. & 10 & Low & \multirow[t]{2}{*}{ Anxiety } & \multirow[t]{2}{*}{1} \\
\hline & & $r_{1, \leqslant 9}$ & $1 \ldots, 9$ & $1 \cdot \wedge, \ldots$ & $1 \cdot, \Lambda$. & 10 & High & & \\
\hline \multirow{2}{*}{$\begin{array}{l}\text { Non } \\
\text { Sig, }\end{array}$} & \multirow{2}{*}{$1, \leqslant 9$} & $\leqslant 9,79$ & $\curlyvee \wedge, \wedge$. & $\wedge \bullet, 0$. & $\wedge, \infty \bullet$ & 10 & Low & \multirow{2}{*}{ Hyperactivity } & \multirow{2}{*}{2} \\
\hline & & ו & $\Delta ৭, \Lambda$. & $\mid r \leq, 0$. & $\mid r, \leqslant 0$ & 10 & High & & \\
\hline
\end{tabular}

It is clear from the previous table that the calculated value of $(Z)$ is less than the tabulated (T) equal to (1.96) at a confidence level of 0.05 and equal to (2.58) at a confidence level of 0.01 at a degree of freedom (18). This indicates that there is no statistically significant difference in anxiety and hyperactivity.

\section{Table 4}

The $\mathrm{T}$ value and its statistical significance of the difference between the means of low and high scores of hyperactivity in relation to oral performance and anxiety:

\begin{tabular}{|c|c|c|c|c|c|c|c|c|c|}
\hline $\mathbf{N}$ & Variable & $\begin{array}{c}\text { Interquartile } \\
\text { range }\end{array}$ & number & $\begin{array}{c}\text { Mean } \\
\text { of } \\
\text { ranks }\end{array}$ & $\begin{array}{c}\text { Sum } \\
\text { of } \\
\text { ranks }\end{array}$ & Median & $\begin{array}{c}\text { St. } \\
\text { deviation }\end{array}$ & $\begin{array}{l}\text { Value } \\
\text { of }(Z)\end{array}$ & Sig. \\
\hline \multirow[t]{2}{*}{1} & \multirow[t]{2}{*}{ Anxiety } & Low & 10 & $\bullet, \Lambda$. & $P, \wedge q$ & $\wedge \wedge, \diamond$. & $\bullet \wedge, \cdots$ & \multirow[t]{2}{*}{ r,0 } & \multirow[t]{2}{*}{$\cdot,+1$} \\
\hline & & High & 10 & $10, r$. & $r \wedge, \Upsilon^{\circ}$ & $199,1$. & lor,.. & & \\
\hline \multirow{2}{*}{2} & \multirow{2}{*}{$\begin{array}{c}\text { Oral } \\
\text { performance }\end{array}$} & Low & 10 & $9,0$. & $r r, r \leq$ & $1+7,7$ & $90, \ldots$ & \multirow{2}{*}{$\cdot, V$} & Non \\
\hline & & High & 10 & $11,0$. & $r \leqslant, \leqslant V$ & $11 \varepsilon, r$. & $110, \ldots$ & & Sig, \\
\hline
\end{tabular}


It is clear from the previous table that the calculated value of $(Z)$ is greater than the tabulated value (T) equal to (1.96) at a confidence level of 0.05 and equal to (2.58) at a confidence level of 0.01 at a degree of freedom (18) with respect to the anxiety variable. This indicates that there was a statistically significant difference in anxiety in favor of hyperactivity, and there was no statistically significant difference in oral performance.

In order to double check the results the researcher calculated the difference between the means of scores of low and high anxious learners in relation to oral performance and hyperactivity:

\section{Table 5}

The $\mathrm{T}$ value and its statistical significance difference of the means of scores low and high anxious learners in relation to oral performance and hyperactivity:

\begin{tabular}{|c|c|c|c|c|c|c|c|c|c|}
\hline $\mathbf{N}$ & Variable & $\begin{array}{c}\text { Interquartile } \\
\text { range }\end{array}$ & number & $\begin{array}{c}\text { Mean } \\
\text { of } \\
\text { ranks }\end{array}$ & $\begin{array}{l}\text { Sum of } \\
\text { ranks }\end{array}$ & Median & $\begin{array}{c}\text { St. } \\
\text { deviation }\end{array}$ & $\begin{array}{l}\text { Value } \\
\text { of }(Z)\end{array}$ & Sig. \\
\hline \multirow[t]{2}{*}{1} & Oral & Low & 10 & $1 ., 7$ & $1,7, \ldots$ & & & \multirow{2}{*}{$\cdot, \cdot \wedge$} & \multirow{2}{*}{$\begin{array}{l}\text { Non } \\
\text { sig. }\end{array}$} \\
\hline & & High & 10 & $1 \cdot, \varepsilon$. & $1, \varepsilon, \ldots$ & $11 \leq, 9$. & $r \varepsilon, 7 r$ & & \\
\hline \multirow{2}{*}{2} & & Low & 10 & 0,00 & $00,0$. & $\leq 7,1$. & $r, 01$ & \multirow{2}{*}{$r, V \leq$} & \multirow{2}{*}{0.01} \\
\hline & 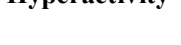 & High & 10 & $10, \leqslant 0$ & $10 \leq, 0$. & 10r,s. & $r q, \cdot r$ & & \\
\hline
\end{tabular}

It is clear from the previous table that the calculated value of $(\mathrm{Z})$ of hyperactivity is less than the value of the tabulated (T) equals (1.96) at a confidence level of 0.05 and equal to (2.58) at a confidence level of 0.01 at a degree of freedom (18). This indicates that there is no statistically significant difference between oral performance and anxiety, and there is a statistically significant difference in hyperactivity in favor of those with high anxiety. 


\section{Discussion of results}

The previously mentioned results revealed that:

- there is no statistically correlation between oral performance and anxiety which means that the higher the anxiety was, the lower the oral performance was. Also, there is a statistically correlation between anxiety and hyperactivity so the higher anxiety was, the higher hyperactivity was, which affected oral performane.

- There is a statistically significant negative correlation between the study participants' oral performance and their FL anxiety level that ranged from very weak to medium. Most of the anxiety dimension was weakly correlated to all the components of the oral performance except for risk taking reluctance and fear of making mistakes due to the nature of the participants.

- There is a statistically significant high positive correlation at 0.01 level between the scores obtained from the administration of the hyperactivity checklist and the FL anxiety scale in most of the dimensions (Communication apprehension, fear of negative evaluation, pressing situation inhibitions, test anxiety and peer approval)except for the risk taking reluctance and fear of making mistakes components which was attributed to the nature of the participants.

The tabulated results shown previously affirmed that the students' oral performance is correlated to their hyperactivity and FL anxiety.

From the data above, the researcher found a statistically significant correlation at 0.01 level between the means of scores of the oral performance test, hyperactivity checklist and FL anxiety. Accordingly, the two hypotheses were statistically rejected. The results denoted that there was a relationship between hyperactivity and oral performance and between hyperactivity and language anxiety. These results were in accordance with the studies of (Basic, 2011; Huang, 2018; Mahmoodzadeh, 2012; Woodrow, 2006; Xianping, 2003). 


\section{Research Recommendations \& Pedagogical Implications}

According to the previously mentioned and discussed results, the researcher recommends the following:

1. Students should be offered enough opportunities to practice speaking on a daily basis using authentic tasks in EFL classes, paying attention to the fact that speaking is a developmental skill that improves gradually.

2. Students should be offered enough comprehensible input through pre-speaking activities and especially through reading in order to provide them with the language necessary for speaking.

3. Students should be provided with effective activities from their real-life situations regarding the speaking skill that enhance their ability to speak.

4. The spoken tasks given to EFL students must be purposeful in order to motivate them to participate.

5. EFL teachers should use pairing up and grouping methods for teaching EFL speaking in a way that lower students' fears and challenge their minds to think and participate.

6. EFL teachers should continuously assess students' oral performance and provide them with constant indirect feedback as this would help them to spot their points of strengths and weaknesses which would reduce their FL speaking anxiety and enhance their speaking performance.

7. EFL teachers should encourage their students to practice speaking outside the classroom.

8. Attention should be paid to reduce students' FL speaking anxiety and motivate them to write using the foreign language.

10. Students should be encouraged to trust in their abilities in oral performance without the fear of failure. 


\section{Suggested Topics for Further Research}

Considering the revealed results, the researcher suggests the following:

Investigating the relationship between:

1. EFL young learners' accuracy level and their anxiety.

2. EFL young learners' writing performance level and their FL speaking anxiety.

3. FL speaking anxiety and EFL young learners' accuracy. 


\section{$\underline{\text { References }}$}

Abu-Rabia, S. (2004). Teachers $\square$ Role, Learners $\square$ Gender Differences, and FL Anxiety Among Seventh- Grade Students Studying English as a FL. Educational Psychology, 24 (5), 711-721.

American Psychiatric Association (2013). Diagnostic and Statistical Manual of Mental Disorders, $5^{\text {th }}$ Ed. Washington, DC: Author

Awan, R.N., Anwar, M.N., \&Naz, A. (2010). An investigation of foreign language classroom anxiety and its relationship with students' achievement. Journal of College Teaching \& Learning, 7(11), 33-40.

Ay, Y. (2010). Young adolescent students' foreign language anxiety in relation to language skills at different levels. The Journal of International Social Research, 3(11), 8391.

Aydin, S. (2008). An investigation on the language anxiety and fear of negative evaluation among Turkish EFL Learners. Asian EFL Journal, Teaching Articles, 30(1), $421-444$.

Aydin, S. (2012). The effects of young EFL learners' perceptions of tests on test anxiety. Education, 40(2), 189-204.

Aydin, S. (2013). Factors affecting the level of test anxiety among EFL learners at elementary schools. E-international Journal of Educational Research, 4(1), 63-81.

Aydın, S., Harputlu, L., Güzel, S., Savran Çelik, Ş., Uştuk, Ö. \& Genç, D. (2016). A Turkish version of Foreign Language Anxiety Scale: Reliability and validity. Paper presented at GlobELT 2016 Conference: An International Conference on Teaching and Learning 
English as an Additional Language, 14 - 17 April 2016, Antalya, Turkey.

Baharuddin, S., S. and Rashid, S., M. (2014) English Language anxiety and oral performance among undergraduate ESL learners. Journal of Language and Communication,1(2), PP.137-154

Baş, G. (2014). Correlation between foreign language anxiety with attitudes towards English course and academic success of high school students. Atatürk Üniversitesi Kazım Karabekir Eğitim Fakültesi Dergisi, 27, 127-146.

Bas, G. (2013). Foreign language learning anxiety scale: Validity and reliability study. Turkish Journal of Social Research, 17(2), 49-68.

Basic, L. (2011). Speaking anxiety: An obstacle to second language learning? (Yayımlanmamış Yüksek Lisans Tezi). University of Gavle, Sweden.

Chen, H. J. (2007). Foreign language anxiety: a study of bilingual elementary school students (Yayımlanmamış Yüksek Lisans Tezi). Chaoyang University of Technology, Department of Applied Foreign Languages, Çin.

Dewaele, N. M., \& Al-Saraj, T. M. (2015). Foreign language classroom anxiety of Arab learners of English: The effect of personality, linguistic and socio biographical variables. SSLLT, $2(2)$, 205-208. doi:10.14746/ssllt.2015.5.2.2

Dörnyei, Z. (2005). The psychology of the language learner: Individual differences insecond language acquisition. New Jersey: Lawrence Erlbaum.

Gan, Z. (2012). Understanding L2 Speaking Problems: Implications for ESL Curriculum Development in a Teacher Training Institution in Hong Kong. Australian Journal of Teacher Education, 37(1), 43-59. 
Hellstén, M. and Prescott, A. (2004). Learning at University: The International Student Experience. International Education Journal, 5(3), Pp.344-352 Retrieved from http://iej.cjb.net.

Hewitt, E., \& Stephenson, J. (2012). Foreign language anxiety and oral exam performance: A replication of Phillips' MLJ study, The Modern Language Journal, 96(2), 170-189.

Horwitz, E. K., Horwitz, M. B. \& Cope J. A. (1986). Foreign language classroom anxiety. The Modern Language Journal, 70(2), 125-132.

Huang, H-T. D. (2018). Modeling the relationship between anxieties and performance in second/foreign language speaking assessment. Learning and Individual Differences, 63, 44-56.

Ihmuda, M. S. (2014). Exploring factors that inhibit EFL learners from speaking English effectively: a case study of Libyan students (Master's thesis), University of Malta.

Liu, H.-J., \& Chen, T.-H. (2014). Learner differences among children learning a foreign language: Language anxiety, strategy use, and multiple intelligences. English Language Teaching, 7(6), 1-13. doi:10.5539/elt.v7n6p1

Liu, M. (2016). Changes, causes and consequences of FLCA: A cohort study with Chinese university EFL learners. European Journal of Applied Linguistics and TEFL, 5(2), 101-120

Liu, M. (2018). Bilingual/multilingual learners' willingness-to communicate in and anxiety on speaking Chinese and their associations with self-rated proficiency in Chinese. International Journal of Bilingual Education and Bilingualism, 21(1), 54-69. doi:10.1080/13670050.2015.1127889 
Liu, M (2006a). Anxiety in EFL classrooms: Causes and consequences. TESL Reporter, 39(1): 13-32.

Liu, M., \& Jackson, J. (2008). An exploration of Chinese EFL learners' unwillingness to communicate and foreign language anxiety. Modern Language Journal, 92(1), 7186.

MacIntyre, P. D. \& Gardner, R. C. (1994). The subtle effects of language anxiety on cognitive processing in the second language. Language Learning, 44(2), 283-305

Mahmoodzadeh, M. (2012). Investigating Foreign Language Speaking Anxiety within the EFL Learner's Interlanguage System: The Case of Iranian Learners. Journal of Language Teaching \& Research, 3(3).

Riasati, M.J. (2011). Language learning anxiety from EFL learners' perspective. Middle East Journal of Scientific Research, 7(6), 907-914.

Richards, J. C., \& Rodgers, T. S. (2014). Approaches and methods in language teaching. Cambridge: Cambridge University Press.

Subasi, G. (2010). What are the main sources of Turkish EFL students' anxiety in oral practice? Turkish Online Journal of Qualitative Inquiry, 1(2), 29-49.

Tanveer, M. (2007). Investigation of the factors that cause language anxiety for ESL/EFL learners in learning speaking skills and the influence it casts on communication in the target language (Unpublished doctoral dissertation). University of Glasgow, U.K.

Woodrow, L. (2006). Anxiety and Speaking English as a Second Language. RELC Journal, 37(3), 308-328.

Yahya, M. (2013). Measuring speaking anxiety among speech communication course students at the Arab American 
University of Jenin (AAUJ). European Social Sciences Research Journal, 1(3), 229-248.

Yan, J. X. \& Horwitz, E.K. (2008). Learners $\square$ perceptions of how anxiety interacts with personal and instructional factors to influence their achievement in English: A qualitative analysis of EFL learners in China. Language Learning, 58 (1), 151-183.

Zhang, W., \& Liu, M. (2013). Evaluating the impact of oral test anxiety and speaking strategy use on oral English performance. The Journal of Asia TEFL, 10(2), 115148. Retrieved from

http://www.earticle.net/article.aspx?sn=201615 